\title{
Powerful Veiled Visions in a Neo-patriarchal Iranian Cinema: A Study of TahmineMilani's Fifth Reaction (2003)
}

\author{
EsmaeilZeiny Jelodar ${ }^{1}$, Noraini Md. Yusof ${ }^{2}$, Khalil Mahmoodi ${ }^{3}$ \\ ${ }^{I}$ (School of Language Studies and Linguistics, National University of Malaysia (UKM), Malaysia) \\ ${ }^{2}$ (School of Language Studies and Linguistics, National University of Malaysia (UKM), Malaysia) \\ ${ }_{3}^{3}$ (Department of English, Abadan Branch, Islamic Azad University, Abadan, Iran)
}

\begin{abstract}
Films about 'women's issues' and their importance in Iran have not been paid in-depth attention in scholarly works. These films are labeled as political as they challenge the institutions and values of patriarchy in Iranian society. In recent years, Iranian women filmmakers have produced an impressive body of work and they have won a number of international awards. These filmmakers carved a niche despite all the restrictions imposed by patriarchal strictures. However, these filmmakers are still facing difficulties in making their films as the political fortunes of the conservatives and reformers continue to ebb and flow. TahmineMilani is one of the Iranian women filmmakers whose films directly address women's problems in a patriarchal society. By providing an overview of the role of women in Iranian cinema and by examining TahmineMilani's Fifth Reaction (2003), this paper sheds light on the role of Iranian women filmmakers and the status of women in Iran. We argue although it has been repeatedly said that Iranian women filmmakers can easily make films about women's issues, there is still a tough hold on women's cinema. We also argue that Iranian cinema has taken a form of neopatriarchy in which women filmmakers are still restricted and at times are not allowed to present women's related issues such as political and social problems of women. In spite of all these vicissitudes, these women filmmakers still have a powerful presence in Iranian cinema.
\end{abstract}

Keywords: Cinema,Iran, NeopatriarchySociety, Women

\section{Introduction}

Filmha-ye-zananehor 'women's film' is a category of social films which bear upon women's issue within a patriarchal dominated society such as polygamy, divorce, child custody, and the imposed dress code. The institutionalized patriarchy of a society feels threatened by these browbeaters as they pose challenges to the patriarchal values and traditions; thereupon, these films actualize negotiations of gender relations. An interest in the role of gender in Iranian cinema was sparked by these movies mostly directed and produced by female filmmakers. These Iranian women filmmakers have produced an impressive body of work and they have won a number of international awards and accolades around the globe.However, these filmmakers have been facing various vicissitudes in making their films as the political fortunes of the conservatives and reformers continue to ebb and flow. In the worst case scenario, their films are banned from screening and at best, they are censored which debilitate the connection between the filmmakers and the audience.

In the supposedly enlightenment era, there is still a tough grip on women's films, although it has been repeatedly said that Iranian women filmmakers can easily make films about women's issues.Undeterred by all these adversities, women still have a sturdy presence in the Iranian cinema. These filmmakers strive to challenge the status quo, overcome the barriers of tradition, patriarchy, and misogyny characteristic of the society. Their films exhibit the lives of women within a patriarchal society riddled with hardships. These films, as Mulvey (1987) argues, confer felicity to women since female viewers enjoy the strong character and wish to emulate the role model's identity (Inness, 2004). These women filmmakers are, indeed, trying to raise awareness amongst the grassroots women in the society. This awareness raising chimes in with feminist consciousness raising which was initiated by the feminists of the Women's Liberation movement in the States in the late 1960s (Zeydabadi-Nejad, 2010).

Zeydabadi-Nejad (2010) asserts that women of this movement decided that instead of commencing with political agendas, "women should draw reflexively on their own life experiences and their emotional responses to them in order to arrive at a collectively defined understanding of injustice in CR (consciousnessraising) groups" (105). This cognizance and consciousness would assist the group members to relate "their own personal lives to feminist perspectives, hence the personal becomes political" (Hanisch, 1978 cited in Zeydabadi-Nejad, 2010). Therefore, these films about women made by women, which are based on personal lives, can be political in the patriarchal society. The next sections provide a bird's eye view of women's status before and behind the camera in the pre and post-revolutionary Iran. 


\section{Women In Pre-Revolutionary Iranian Cinema}

Iran possesses long cinematic annals. In 1900, the first Iranian documentary was filmed and in 1904, the first public theater inaugurated; the first feature film was screened in 1930. In 1960s and 1970s, Iranian film industry produced a great number of films which won awards and recognition in international film festivals (Naficy, 1995). Some current acclaimed filmmakers carved a niche for themselves during this period.

Right from the start, women involvement in Iranian cinema has been replete with various problems. Owing to religious creeds, women were repudiated an entry in visual art performances and even in Persian classical poetry (Chelkowski, 1979; Najmabadi, 1999).The Lore Girl (1933), the first Iranian talkie, featured SediqehSaminejad. As the very first woman to appear on film, she faced physical abuse and vitriolic criticism onstage, offstage, and years afterwards (Zeydabadi-Nejad, 2010). The concurrent movie, Haj Aqa, the Cinema Actor, featured the problematic theme of women acting in films. The film centers on a traditional man, Haj Aqa, who disallows his daughter to act in films. Clandestinely filming him when he does his daily business, the filmmaker screened it. When Haj Aqa, later, sees himself on the big screen and experiences the cheer by the onlookers, he changed his mind and allows his daughter to act in films. However, in real life situation, men would never allow their daughter to act. The director of Haj Aqa, the Cinema Actor, Oganians opened an acting school in Tehran which unsurprisingly failed in having any female students (Baharlu, 2002).

During 1960s and 1970s, cinema has seen a dramatic increase in the number of actresses with the popularity of film-e-farsi. In the words of Lahiji (2002, p. 219), these women played the role of "unchaste dolls" whose mere function was to "display their bodies to satisfy the poor film-goers"; cinema of that time had treated women more like objects or commodities. Women had no agency in the films and the films stubbornly adhered to patriarchal values. In these films, the typical young woman leaves home as she was cajoled into sex by a man who would leave her subsequently. Losing her virginity and shame, she would end up in dancing, singing and prostitution. A male hero usually saves this woman, direct her to the right path, then marries her and she becomes chaste (Zeydabadi-Nejad, 2010).

The representation of women as objects of desire in the cinema created anti-cinematic feelings which run deep in Iran before the Iranian revolution of 1979. The religiously minded people and the clergies condemned cinema as they saw it as "morally offensive and an ethically corrupting Western influence" (Naficy, 1995 , p. 548); that was the major reason for them to declare cinema 'haram' or religiously prohibited. These clerical leaders viewed cinema as an ideological apparatus which was imported in the country from the West by the Pahlavi regimes (1925-1979) to Westernize Iran. Mir-Hosseini (2003) argues that the traditional clergy felt it disturbing to represent women as a sexual commodity as they were of the idea that women sexuality was intrinsically perilous to social order. The late Ayatollah Khomeini also compared cinema to harlotry but he did support cinema only if it was used rightly: teaching and stressing the 'Islamic values.' In his first speech upon returning to Iran, he stated:

We are not opposed to cinema, to radio, or to television.... The cinema is a modern invention that ought to be used for the sake of educating the people, but as you know, it was used instead to corrupt our youth. It is the misuse of cinema that we are opposed to, a misuse caused by the treacherous policies of our rulers (Ayatollah Khomeini cited in Naficy, 1995, p. 548).

\section{Women In Post-Revolutionary Iranian Cinema}

After the toppling of the Shah by the Iranian revolution in 1979, the Iranian film industry sank into a state of hibernation. Following the inauguration of the Islamic Republic (1979), many prognosticated that the new restrictions and impositions would kill off the cinema in Iran,but through extraordinary metamorphosis, Iranian cinema has survived; it soon was at full throttle and currently it is producing more than 100 feature films annually (Bahar, 2010).Cognizant of cinema's power, the state's authorities neither denied nor overlooked the cinema as the clergies had done so before (Mir-Hosseini, 2001). Ayatollah Khomeini made an attempt to adopt cinema instrumentally, that is, to bring it under the domination of state ideology in order to battle Western culture through a process of Islamization (Naficy, 1995; Mir-Hosseini, 2001). In her article Women in a widening fame: (Cross-) Cultural projection, spectatorship, and Iranian cinema, Lindsey Moore (2005, p. 6) confirms that:

From its inception, the content of Iranian cinema has been strongly influenced by a dominant national political ideology. Since the Iranian Revolution of 1979, as in the Pahlavi era, the state has censored political dissent and provided financial support for films that positively reflect government policy. Iranian cinema's greatest crisis came in the buildup to the revolution, when the clergy defined film as an agent of cultural colonization, and arson attacks were made on cinemas throughout the country. The industry was resurrected, however, because the Islamic state recognized its value in transmitting both ideology within Iran and a more benevolent national image beyond 
its boundaries to offset the negative stereotypes produced through the Salman Rushdie affair and the hostage crisis of 1979-80.

Following the Revolution of 1979, the Islamic Republic attempted to bring culture and art under its grip. The Ministry of Culture and Art transmuted into the Ministry of Culture and Islamic Guidance (MCIG), with a decree to Islamize all kinds of art and cultural activities (Mir-Hosseini, 2001). Through the Islamization of cinema, women were allowed to enter acting only if they appeared modest in their appearance and behavior as they had to abide the rules of dress code, hejab. Close- up shot of women who were young and attractivewas forbidden (Zeydabadi-Nejad, 2010). Representation of women on screen became a major bone of contention. Consequently, many filmmakers ignored women altogether so as to shun controversy. No quality film was produced during the immediate years after the revolution; and conspicuously absent from those films were women and love (Mir-Hosseini, 2001).

Women had to appear with head cover and loose dress as to conceal their bodies if wished to act. Unfortunately, no space can be exclusively private for the women in Iranian cinema; "the public intrudes and collides via a spatial and social estrangement that is imposed through the mechanism of the hejab. The putative gendering of spaces is elided through hesitations enforced by cinematic censorship as well" (Niazi, 2010).Thus, the appearance and conduct of all performers in Iran is regulated by the fact that in Iranian cinemaall spaces are considered as public. The post-Revolutionary Iranian cinema was formed under such regulatory censorial circumspection. Some eagerly embraced the code, some looked for strategies of metaphor and symbolism to bypass a physicality that was officially proscribed, and finally, filmmakers such as Kiarostami, decided not to deal with relationships, bodies, and spaces that had to be "misrepresented in order to be represented" (Khosrowjah, 2011, p.57). He would not exhibit a home in which the woman had to wear hejab in front of herhusband, son, and brother. This can be confirmed by Kiarostami's following assertion:

Overall, I don't pick subjects involving husbands and wives in their apartment or room, because when you make a movie you have to believe the story yourself. We put a series of lies together. For example, to show the truth of a family, we don't have to use a real family. We may get the husband from somewhere, the wife from somewhere else, borrow a child and rent an apartment. But the combination of all these things should give us an exact definition of the family. And the definition is quite clear to all of us. It's a unit in which people have a relationship with total privacy and security with one another. A child would not have any designs on the mother and the husband has no problems with his wife's hair. But what if I looked through my viewfinder? They have no real relationships with each other. We work so hard to say that despite all those "lies" we try to demonstrate a concept, the concept of a family. So I won't be able to define a family when I realize that I can't show it the way I've lived it. I remember that my father could see my mother's hair. As a child I never had a problem caressing my grandmother's hair. So this is a family I don't know, and since I don't know it, I won't touch it. By that I mean to say that I have automatically avoided thinking about relationships between men and women within households. Maybe this is why I unconsciously keep going to the villages to make films.(Kiarostami from an interview in the supplementary materials on the 1999 Taste of Cherry DVD/VHS release).

Gradually, however, strong female characters emerged since mid-1980s; there was a dramatic shift from being background presence to predominant characters. Films such as Beizai'sBashu, the Little Stranger (1985), broke the prior cliché characterizations of women and presented a strong female character. Breaking traditional customs, women not only were active in front of the camera, but also they were quite active behind the camera directing and producing feature films. Filmmakers such as RakhshanBani-Etemad, TahminehMilani, PuranDerakhshandeh are regarded as the firstfew women filmmakers in post-revolutionary Iran. Along with some other female filmmakers like Samira Makhmalbaf, ManijehHekmat, and MarziyehMeshkini, these female filmmakers produce films about women, love and women's problems in the patriarchal society. Their filmmaking heavily hinges on the dominantpolitical wing of the society. The reformists usually relax their grips and the imposed restrictions; consequently, films about women's issue appear in cinemas. The conservatives tighten their holds and the imposed restrictions; subsequently, films about women issuewould be censored or banned from screening.

Makhmalbaf'sTime of Love (1991) and Bani-Etemad'sNarges (1992) were the first two films which broke the taboo subject of romantic love. Time of Love presents three versions of a married woman's love affair and Narges is the first film about love triangle of two women and a man (Zeydabadi, 2010).In breaking new grounds for the representation of women, the two films of Milani'sTwo women (1999) and Jeyrani'sRed (1999) could be regarded as pioneer films of the post-revolution's cinema. To illustrate this point, Red is about a 
woman, who has been tormented everyday by her abusive husband; in an exceptional and unprecedented ending, the woman kills her abusive husband.

These films followed by a great number of films about women are indicative of the fact that the state eased the restrictions on filmmakers producing films about women and italso could be argued that the state is not following the patriarchal tradition. However, the truth of the matter is that a different form of patriarchy is at work which is called 'neopatriarchy'; these filmmakers, especially women filmmakers, face severe criticism and are accused of generalization and misandry. Some of these women filmmaker are not allowed to make any more movies on women. In an interview with Jeirani in 7, an Iranian cinema show, Milani states that "I've been told not to make any movies about women's problems." These men of top brass positions "whose feet are not on the solid ground of patriarchal tradition, while wanting to be modern, cannot yet accept the reality of educated women in Iran today" (Zeydabadi-Nejad, 2010, p. 105).

The claim to be modern in the modern time conjures upSharabi's concept of neopatriarchy. The term 'neopatriarchy' refers to the conditions of patriarchy in a society that have not been transformed or modernized altogether. Rather, they have only been bolstered and maintained in distorted and somehow modernized forms. Irrespective of modern institution building and legislation suggestive of modern ideas, theneopatriarchal state "is in many ways no more than a modernized version of the traditional patriarchal sultanate"(Sharabi, 1988, p. 7).This serves true about the current conditions in Iran where society is encircled by modern surroundings but the patriarchal perspectives still overshadows. The fact that the state had recently declared some university majors unfit for female students is indicative of the presence ofneopatriarchy.

\section{Women's Cinema In Post-Revolutionary Iran}

An array of factors caused the change towards women's cinema in Iran including modifying the cultural policies of the Islamic Republic that permitted for more concentration on the woman's image, the shifts in cultural use patterns that were gradually putting women and youth as the chief consumer of cultural products,and the appearance of some filmmakers who recognized social commitment as a core part of their cinema(Dadar, 2012). Dadar (2012) opines that auteurs such as Bani-Etemad, Milani, Sadr Ameli, Afkhami, and Farhadi developed their own social realist styles in which the image of women become central to the realist claims.

The seemingly repressive Islamic regime, in fact, facilitated women's access into the cinema; by Islamizing the cinema, the state paved the way for a cinematic profession for women. Academic organization including the IRIB University, the Islamic Center for Filmmaking, and the Society of Youth Cinema joined with a number of private institutions teaching filmmaking provided an educational environment for the gung-ho (RavadRad, 2007). It was after the 1979 revolution that the first generation of female filmmakers such as BaniEtemad and Milani made their feature films. Although faced with ups and downs in the patriarchal society, they found ways to circumvent the strict rules and regulation. Soon the cinema was inundated with brilliantly young and attractive actresses: NikiKarimi, Leila Hatami, HediehTehrani and later on joined by PegahAhangarani, BaranKowsari, TaranehAlidoosti, and GolshiftehFarahaniwho became the faces of defiant female characters in Iranian cinema. Currently, Iranian actresses have a leeway of showing strands of hair and the regulations on them are not as tough as the immediate years after the revolution. Womennot only sustained their presence in the Iranian cinema, but they also made their presence a powerful one, despite all the strictures. In an interview with Zeydabadi-Nejad (2010, p. 123) on how she makes women's films despite all the restrictions, Milani asserts:

this place has its own laws, and you can zigzag through. I use a trick, in order to say what I want. For example, if I know that a woman whose children are taken from her is in the right, I will protest against it. But this is a delicate matter and you have to be careful how you protest. For example, if in Fifth Reaction I had questioned the custody laws, my film would have never got a permit. I question the law that says the child does not belong to the woman by asking the question whether that is possible under these conditions. So, I zigzag through. After seeing my film, the viewer is going to say, how namard [cowardly; the opposite of javanmard] they are to take her children from her. See what a trick I use to say what I want. For example, in Two Women Fereshteh wants to go to university. Is there anything more basic than what she wants? But here, for a woman to study, she needs the permission of her father or her husband. To approach this problem I get the girl to say to her father, ' I want to study in order to be able to help you and my siblings. 'This gives legitimacy to the girl's desire to study; and then I pose the question, ' Why don't you let her study?' This is how I can enter their hearts. If I said, 'I am a feminist, the feminists ' in the world would laugh at me. That type of feminism has no meaning here. But I can say 
that I do my best to stand against discrimination against women. That is all I can do here.

The above assertion proves that a filmmaker such as Milani still keeps her presence a potent one against all odds. The fact that she zigzags through the regulations is suggestive of her brilliance to protest against the patriarchal society. She intends her film to raise awareness for the grassroots women within the society.

\section{Fifth Reaction (2003)}

Milanihad studied architecture at university in 1980s. During the early 1980s when the state closed all the universities due to the so-called Cultural Revolution, Milani started working in film studios. Having worked for some years, Milani made her first feature film, Children of Divorce (1989). Usually Nikbin, her husband, is producer of her films. Three years after Children of Divorce, her comedy film, What's New? (1992) became the bestselling film of that year. However, Milani is known and got recognition because of her Two Women (1999) which confirmed her position as a filmmaker dealing with women's issues (Zeydabadi-Nejad 2010).Two women centers on the lives of two female students Starring NikiKarimi and MerilaZare'i. One marries her classmate and becomes a successful professional and the other coming from a lower middle class, small town family, becomes the victim of the evil intentions of her psychotic stalker/lover.

Her next film, Hidden Half (2001), starring NikiKarimi, focuses on the brief period of political freedom in the immediate years after the revolution when the universities were the hub of political activities in Iran. This film led to Milani's arrest and imprisonment.She was released after six days but became better known as a controversial and outspoken filmmaker (Zeydabadi-Nejad, 2010). Her next film, Fifth Reaction, released in 2003 deals with the life of Fereshteh, starring NikiKarimi, a mother of two young boys bereft of her husband. Living with her in-laws, her father-in-law, Haj Safdar, a traditional man and the head of a large truck driver's guild, asks her to leave his house and leave the children with him. She finally leaves the house and is allowed to visit her children on weekends. Upon hearing that Haj Safdar is sending the kids to their aunt in Isfahan, Fereshtehdecides to flee with her children.

Fifth reaction opens with a frame of five well-educated women lunching at a fine restaurant, sharing the joyful experiences of their lives. They keep talking about love and married life; each of them boasts of loving husband and how their husband love them so much. Fereshteh keeps listening as she has just lost her husband. In the same scene, Taraneh tells Fereshte that she has to be thankful as she still has her father-in-law to support. Apart from Parisa who is single, they all believed that a man is needed in their lives for support. By presenting this frame, Milani implies that this is the way the cookie crumbles in the patriarchal society;women are partly to be blamed as they believe man is a superior figure to be relied upon.

As the film proceeds, the first problem emerges during lunch. Taraneh's husband enters the restaurant with his twenty-year-old secretary, and soon realizes that his wife is also present at the restaurant. He goes over to her table and heaps a vitriolic tirade on her stating that it is the impropriety of women dining out when they should be at home, attending to domestic responsibilities. The husband orders his wife to go home, but she objects.A man rules the roost in a patriarchal society; he is free to do anything but his wife is not. He can go out with an opposite sex but his wife is not allowed to have lunch with her same sex friends. This is what Milani tries to object in her film. Some women know that their husband has extra-marital affair but they keep quiet to save face.

Seeing this, everyone's mask is off and the other women got it out of their chests. Farideh lets her friends know that her opium-addicted husband married another woman and she would not want to file a divorce as she believes her daughters need a father figure. Nasrin's husband who was a prisoner of war for 12 years has changed from a loving husband to an unloving one; Nasrin does not love him anymore and she would not want to divorce him as she says if she files for divorce, she would be blamed for divorcing a war champion. Taraneh,then resolves to teach her husband a lesson. She goes home, packs her bag and lives with her sister until her husband comes to his senses and apologizes. Her strategy works and in two weeks' time she is back home to her husband who gives her a new automobile as a make-up gift.

The second problem which occupies most of the rest of the film touches uponFereshteh, the underpaid schoolteacher and the mother of two sons.Haj Safdar, Fereshteh's father-in-law, orders her to move back to her father's home, leaving the children behind with him while giving Fereshteh visitation rights. Haj Safdar tells her that because she is now a widow, she no longer has any legal ties with the men in the family, so he is asserting the right to say who will live in his house, believing that the two children will be better off living with someone rich. Fereshteh, however, implores Haj Safdar that the boys need a mother irrespective of her income level. Haj Safdarjustifies his decision by saying that "everything should be at its place: a flower in the vase, bread in the bread bin, and a widow at her father's house." Then, he offers a compromise: "you can stay in the house with the two sons on one condition: marry Majid." Majid is another son of Haj Safdar and Fereshteh's brother-in-law. Rejecting the offer, Fereshteh leaves the house and sees the boys on weekends. Milani attacks the patriarchal values and rules of the society by portraying this scene. 
One day, Fereshteh learns that the boys will be soon sent to Isfahan, and she fears that the boys may soon be sent to live with their aunt in Singapore for good. Consequently, she consults with her friends who come up with a solution: fly to Dubai and get a job with the help of a friend of Farideh. However, Haj Safdar doubts that she is about to run way, so he chases her as she goes to the airport in her friend's car. The plan to go to Dubai fails; Fereshteh, then decides to evade him by leaving the country instead by boat. Fereshteh heads to the Persian Gulf, living in houses of friends along the way, but Haj Safdar remains in hot pursuit. In one instance en route to locating Fereshteh, Majid tells his father that he is losing the game and Haj Safdar replies "a rival should be powerful, even if it is zaiefeh"; 'zaiefeh' is a term used by a patriarchal man to refer to women which literally means a weak woman.

When he finally locates her in Bushehr, the port city, he reports her to the police who take her into custody.Zeyrmadineh,Fereshteh's brother landlady, who has much influence in the area, lectures Haj Safdar on the need of children for their mother. Warning him of her local influence, she says she will not allow Haj Safadr to take away the children. He goes into the cell and tells Fereshteh that she can keep the children "on one condition." It is unfortunate that the end of the films shows Fereshteh inside the prison cell which can be a metaphor for women's eventual imprisonment within a patriarchal society.The movie ends without telling audience about that condition. The Fifth Reaction"identifies a host of customs and government regulations that favor men over women in Iran, all to the detriment of the best interests of children as well as women, and thus is a plea for gender equality" (PFS Film Review cited in http://www.geocities.com/polfilms/fifthreaction.html)

\section{Conclusion}

Women's involvement with cinema has been riddled with so many barricades. Before the 1979 revolution, women were used as 'unchaste dolls' actresses to attract audiences and there was hardly any female directors. However, in post-revolutionary Iran, cinema experienced a remarkable shift although the first few immediate years after the revolution, it virtually came to a halt. From mid-1980s, women became active and were the focus of some movies. Both behind and before the camera, these women broke the tradition and fought the systematic injustices. They challenge the inscribed inequity in the patriarchal laws.It is quite worthy of mention to state that female filmmakers confront more barricades than men do and the censors block films with feminist perspective. Despite all these patriarchal regulations, Milani and her female colleagues sustain their potent presence byzigzagging through and by adapting their scripts to lessen the chance of being censored.

\section{References}

[1] Mulvey, L., Notes on Sirk and Melodrama, in C. Gledhill (Ed.), Home is where the heart is: studies in melodrama and the women's film, (London: BFI Publishing, 1987).

[2] Inness, S., Boxing gloves and bustiers: new images of tough women, inS. Inness (Ed.), Action chicks: new images of tough women in popular culture, (New York: Palgrave Macmillan, 2004).

[3] Zeydabadi-Nejad, S., The politics of Iranian cinema, (New York: Routledge, 2010).

[4] Naficy, Hamid, Iranian Cinema under the Islamic Republic, American Anthropologist, New Series, 97(3), 1995, 548-558.

[5] Chelkowski, P., Ta'ziyeh: Ritual and drama in Iran (New York: New York University Press, 1979).

[6] Najmabadi, A., Reading for gender through Qajarpaintings, in L. Diba (Ed.), Royal Persian paintings: the Qajar epoch, 1785-1925, (London: 1.B. Tauris, 1999).

[7] Baharlu, A., Sad chehreh-ye sinema-ye Iran( One hundred faces of Iranian cinema) (Tehran: Nashr-e qatreh, 2002).

[8] Lahiji, S., Chaste dolls succeed unchaste dolls: women in Iranian cinema since 1 979, in R. Tapper (Ed.), The new Iranian cinema: politics, representation and identity, ( London: LB. Tauris, 2002).

[9] Mir-Hosseini, Z., The construction of gender in Islamic legal thought and strategies for reform, Hawwa, 1(1), 2003, 1-28.

[10] Bahar, M., Religious identity and mass media: The situation of women in Iranian cinema following the Islamic revolution, Media and communication studies, 2 (6), 2010, 144-153.

[11] Mir-Hosseini, Z., Iranian Cinema: Art, Society and the State, Middle East Report, no. 219, 2001, 26-29.

[12] Moore, Lindsay, Women in a widening frame: (Cross-) Cultural projection, spectatorship, and Iranian cinema, Camera Obscura, 20(2), 2005, 1-33

[13] Niazi, S., Urban imagination and the cinema of JafarPanahi, Wild Screen, 1(2), 2010, 1-14.

[14] Khosrowjah, H., Neither a victim nor a crusading heroin', Situations: Project of radical imagination, 4(1), 2011, 53-65.

[15] Sharabi, H., Neopatriarchy: a theory of distorted change in Arab society, (New York: Oxford University Press, 1988).

[16] Dadar, T., Reading against the veil: Gender and politics in popular cinema of post-revolutionary Iran, doctoral diss., Queen Margaret University, 2012.

[17] Ravadrad, A. and Zandi, M., Avamel-e Moasser bar Sheklgiri-e SinamayeZandar Iran (The effective factors on formation of women's cinema in Iran), Motale'at-e-Zanan, 4(3), 2007, 23-40.

[18] The Fifth Reaction, PFS Film Review, available form http://www.geocities.com/polfilms/fifthreaction.html 